\title{
Archiving time series sewage samples as biological records of built environments
}

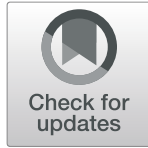

David S. Thaler ${ }^{1,2,3^{*}}$ (1) and Thomas P. Sakmar ${ }^{3}$

\begin{abstract}
This commentary encourages the regular archiving of nucleic-acid-stabilized serial samples of wastewaters and/or sewage. Stabilized samples would facilitate retrospective reconstitution of built environments' biological fluids. Biological time capsules would allow retrospective searches for nucleic acids from viruses such as SARS-CoV-2. Current resources for testing need not be diverted if samples are saved in case they become important in the future. Systematic storage would facilitate investigation into the origin and prevalence of viruses and other agents. Comparison of prevalence data from individual and clinical samplings with community wastewater would allow valuable comparison, contrast and correlation among different testing modalities. Current interest is focused on SARS-CoV-2, but archived samples could become valuable in many contexts including surveys for other infectious and chemical agents whose identity is not currently known. Archived time series of wastewater will take their place alongside other biological repositories and records including those from medical facilities, museums, eDNA, living cell and tissue collections. Together these will prove invaluable records of the evolving Anthropocene.
\end{abstract}

Keywords: SARS-CoV-2, Covid-19, Virus, Sewage, Wastewater, Sample archiving, Historical epidemiology, Public health, Biological diaries

\section{Background}

The purpose of this commentary is to encourage the regular archiving of nucleic-acid-stabilized serial samples of untreated waste water and sewage from multiple systems and subsystems of our built environment. There is an important literature on preserving wastewater samples $[1,2]$ for chemical analysis. Nucleic acid-stabilized samples could preserve materials allowing future insights into the biological fluids of built environments, including evidence of viruses such as SARS-CoV-2. Imagine if we had a series of samples before and during the arrival of SARS-CoV-2 into a city, apartment block, or cruise ship. Retrospective analysis would enrich the investigation of questions about the origin and prevalence of the virus,

\footnotetext{
* Correspondence: david.thaler@unibas.ch; davidsthaler@gmail.com

'Biozentrum, University of Basel, CH-4056 Basel, Switzerland

${ }^{2}$ Program for the Human Environment, Rockefeller University, New York, NY, USA

Full list of author information is available at the end of the article
}

which would be answerable in a more objective way than other methods allow.

There is a significant and rapidly growing literature on SARS-CoV-2 virus detection in sewage, including tracing the virus to specific buildings; surely more use of sewage for "real time" analysis will come [3-11]. It seems too late for archived samples to allow tracing the first, or second waves in many locales but the need to monitor infection will certainly continue. Retrospective information will inform the analysis and understanding of public health measures, for example, how restrictions influenced subsequent viral load in a community. Testing of individuals is vulnerable to different sampling biases than averaging the collective biological fluid of a larger community. Comparison of prevalence data from individual and clinical samplings with community sewage would allow valuable correlation that may help dispel critiques such as "More testing results in more positive cases." [12].

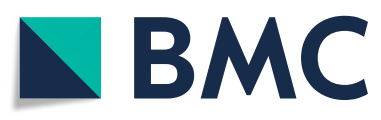

(c) The Author(s). 2021 Open Access This article is licensed under a Creative Commons Attribution 4.0 International License, which permits use, sharing, adaptation, distribution and reproduction in any medium or format, as long as you give appropriate credit to the original author(s) and the source, provide a link to the Creative Commons licence, and indicate if changes were made. The images or other third party material in this article are included in the article's Creative Commons licence, unless indicated otherwise in a credit line to the material. If material is not included in the article's Creative Commons licence and your intended use is not permitted by statutory regulation or exceeds the permitted use, you will need to obtain permission directly from the copyright holder. To view a copy of this licence, visit http://creativecommons.org/licenses/by/4.0/ The Creative Commons Public Domain Dedication waiver (http://creativecommons.org/publicdomain/zero/1.0/) applies to the data made available in this article, unless otherwise stated in a credit line to the data. 
Biological diaries, archives, and culture collections are invaluable in contexts including medical repositories, museums, collections of living and revivable tissues and cells in biobanks, seed banks of biodiversity, and many other contexts $[13,14]$. Biological diaries of built environments stored and analyzed in similar ways to analogous time-series repositories from less-human-centered environments could synergistically deepen understanding of the dynamic and evolving Anthropocene. There is a recognized need for better biobanks from complex microbial systems [15].

\section{Main text}

Historical samples have proven important in tracing the origin and spread of infectious diseases in previous instances. However, in the cases of which we are aware, biological materials were originally collected for other purposes. Molecular methods of analysis used, to study the origin of HIV, for example, were not even dreamed of at the time samples were taken [16]. Molecular reexamination of medical samples from the 1918-1919 flu pandemic led to the interpretation, nearly 100 years later, that much mortality was due to secondary bacterial pneumonia [17]. The storage and availability of samples ready for nucleic acid sequence studies has often been haphazard, perhaps because there has been insufficient articulation of their value.

There are many contexts for which a properly preserved time series of biological samples of built environments are potentially of inestimable value. Archeologists and physical anthropologists make good use of the information obtained from ancient latrines, valuable biological time capsules that were not deliberately created [18-22]. Museums and other collections and repositories contain materials that can be explored again and again as new methods are developed and the value of information obtainable from these samples is realized.

Environmental DNA (eDNA) is increasingly recognized and used for species assays in aquatic systems to supplement or partially replace trawl or other macroscopic methods of census [23, 24]. Methods are being refined to make archiving and subsequent information extraction more efficient, but approaches for reliable archiving of microbiome and other biological samples, indefinitely, at ambient temperature, are already well established $[25,26]$. The key point is that it is not even necessary to isolate nucleic acids right away.

Leonardo Da Vinci conceived of Earth and also architectural entities such as cities as akin to living organisms [27]. The consideration of houses and cities as bodies was an important part of new and influential conceptualizations in public health that began in late nineteenthcentury England and continue to influence architecture and urban design $[28,29]$. Cross-fertilization between innovations of precision medicine as applied to individual patient care and "precision public health" are especially relevant in the context of infectious disease (and in a hopeful future, of infectious health [30, 31]). Biological archiving of samples has promise in both contexts of individuals and of environments, be they built, natural, or any combination.

Analytic methods are likely to improve over the coming years and to increase the information that can be obtained from archived samples. The most exciting developments might be unanticipated, but some possibilities for innovation are outlined below.

\section{Contexts and scenarios where nucleic acid stabilized wastewater samples could help}

Retroactive analysis of wastewater samples has the potential to inform epidemiology, kinetics in closed and semi-closed systems, and the understanding of microbial evolution in built environments. Sewage samples archived for other purposes and stored at $-20^{\circ} \mathrm{C}$ have been retroactively assayed for SARS-CoV-2 and found positive [32]. When did a virus first begin to spread in a city, or on a particular cruise ship, aircraft carrier [33], or future interplanetary expedition? How quickly did the public titer of virus change? Does public virus titer follow a logistic curve or other kinetic as predicted by various models? How did various public health measures such as lockdowns, quarantines, mask wearing, affect the public pool of virus?

Consider the controversy concerning the origin of SARS-CoV-2 [34-38]. Archived samples of building sewage from relevant laboratories, markets, and neighborhoods would be of inestimable value in providing more threads to pull on in order to better understand what has happened. One thing is certain: This SARSCoV-2 outbreak will not be the last pandemic, even as it is not the first whose origin has been controversial (e.g. [39-41]).

The number of positive cases determined from individual tests has several uncertainties. How are people to be tested chosen? The kinetics of viral appearance and disappearance in individuals are uncertain variables. The shared fluid of built environments is a complementary sampling strategy that pools all the individuals, and with statistical qualifications has been found to agree reasonably well with individual sampling from the community [42]. Depending on how sampling is done, sources can be pinpointed in both space and time, for example to branch points in the collection system.

PCR and rtPCR based methods for virus detection now largely depend on having the target sequence in hand. Non-targeted detection methods are becoming more sophisticated, allowing detection of genetic elements and agents that have not been previously defined. 
Potential nucleic-acid targets include viruses, bacteria, protists, parasites, and antibiotic-resistance genes on plasmids. More speculatively, and dependent upon engineering beyond today's norms, there is a possibility that viral nucleic acid in sewage is present inside host cells. Single cell isolation might allow identification of infected individuals directly from wastewater. This future technical capability raises questions concerning conflicts of privacy and public health [31].

The storage of samples for future nucleic acid analysis is currently not as widespread as its potential suggest it should be. What nudges [43] might encourage wider adaptation and what impediments might be ameliorated? At present the standards for sample preservation require either perpetual storage in the frozen state or the addition of nucleic acid stabilizing solutions that allow room temperature storage [25]. Room temperature storage volumes are large so that either method requires considerable resources. Purified nucleic acids are compact and stable for storage but processing samples is time-sensitive and resource demanding. Physical anthropological and forensic approaches have proven the ability to recover valuable sequence information from samples stored in a variety of ways and circumstances. There is a need for the convergence of approaches to sample archiving along with the appreciation of their future benefits and resources to apply them.

\section{Conclusions}

Current sewage analysis includes some pharmaceuticals, cosmetics, illegal drugs, viruses, pesticides and other chemicals of concern [44-47]. The future is likely to see ever greater sophistication of analysis and expansion of the number of targets relevant to public health as well as increasing capacity for analysis as resources grow and/or become available with the passing of emergency situations. In anticipation, we encourage further sampling and preservation from built environments in order to prepare for a future that is able to efficiently utilize them [48]. Sample availability will enrich deeper historical understanding of what is unlikely to be the last pandemic [49]. Archiving samples now will enable the future's understanding of its past and inform preparations for future challenges [50].

\section{Acknowledgements}

Thanks to Jesse Ausubel, David Burg, Thomas Huber, Manija Kazmi and Mark Stoeckle for valuable discussions.

\section{Authors' contributions}

DST drafted, DST and TS both contributed intellectually. The author(s) read and approved the final manuscript.

\section{Funding}

The Program for the Human Environment and the Laboratory of Chemical Biology and Signal Transduction, Rockefeller University, USA.
Availability of data and materials

Not applicable.

\section{Declarations}

Ethics approval and consent to participate

Not applicable.

Consent for publication

Not applicable.

Competing interests

None.

\section{Author details}

${ }^{1}$ Biozentrum, University of Basel, $\mathrm{CH}-4056$ Basel, Switzerland. ${ }^{2}$ Program for the Human Environment, Rockefeller University, New York, NY, USA. '3aboratory of Chemical Biology and Signal Transduction, Rockefeller University, New York, NY, USA

Received: 8 December 2020 Accepted: 2 June 2021

Published online: 24 June 2021

\section{References}

1. Sd G, Adams GO. The collection and preservation of samples of sewage for analysis. J Infect Dis. 1906;3:139-48.

2. Kalkhajeh Y, Amiri B, Huang B, Khalyani A, Hu W, Gao H, et al. Methods for sample collection, storage, and analysis of freshwater phosphorus. Water. 2019;11(9). https://doi.org/10.3390/w11091889.

3. Developing a Wastewater Surveillance Sampling Strategy [https://www.cdc. gov/coronavirus/2019-ncov/cases-updates/wastewater-surveillance/ developing-a-wastewater-surveillance-sampling-strategy.html].

4. Orive G, Lertxundi U, Barcelo D. Early SARS-CoV-2 outbreak detection by sewage-based epidemiology. Sci Total Environ. 2020;732:139298. https://doi. org/10.1016/j.scitotenv.2020.139298.

5. Barcelo D. An environmental and health perspective for COVID-19 outbreak: meteorology and air quality influence, sewage epidemiology indicator, hospitals disinfection, drug therapies and recommendations. J Environ Chem Eng. 2020;8(4):104006. https://doi.org/10.1016/j.jece.2020.104006.

6. Mallapaty S. How sewage could reveal true scale of coronavirus outbreak. Nature. 2020;580(7802):176-7. https://doi.org/10.1038/d41586-020-00973-x.

7. Sen-Crowe B, Boneva D, Elkbuli A. Municipal Sewage COVID-19 Testing: A Much Needed Public Health Community Prevention Intervention. Am Surg. 2020;86:1518-19.

8. Michael-Kordatou I, Karaolia P, Fatta-Kassinos D. Sewage analysis as a tool for the COVID-19 pandemic response and management: the urgent need for optimised protocols for SARS-CoV-2 detection and quantification. J Environ Chem Eng. 2020;8(5):104306. https://doi.org/1 0.1016/j.jece.2020.104306.

9. Baraniuk C. Sewage monitoring is the UK's next defence against covid-19. BMJ. 2020:370:m2599.

10. Rooney CM, Moura IB, Wilcox MH. Tracking COVID-19 via sewage. Curr Opin Gastroenterol 2020;37:4-8.

11. Amahmid O, El Guamri Y, Rakibi Y, Ouizat S, Yazidi M, Razoki B, Kaid Rassou K, Asmama S, Bouhoum K, Belghyti D. Occurrence of SARS-CoV-2 in excreta, sewage, and environment: epidemiological significance and potential risks. Int J Environ Health Res. 2021:1-21. Published online ahead of print.

12. Trump D: Transcript: 'Fox News Sunday' interview with President Trump President Trump appeared on 'Fox News Sunday' with Chris Wallace on July 19. In: Fox News. Edited by Wallace C. https://www.foxnews.com/politics/tra nscript-fox-news-sunday-interview-with-president-trump; 2020.

13. Schindel DE, Cook JA. The next generation of natural history collections. PLoS Biol. 2018;16(7):e2006125. https://doi.org/10.1371/journal.pbio.2006125.

14. Schindel D. Collections. atESGotIWGoS: Economic Analyses of Federal Scientific Collections: Methods for Documenting Costs and Benefits. Report. Washington, DC: Smithsonian Scholarly Press; 2020. https://doi.org/10.5479/ si. 13241612

15. Ryan MJ, Schloter M, Berg G, Kostic T, Kinkel LL, Eversole K, et al. Development of microbiome biobanks - challenges and opportunities. Trends Microbiol. 2021;29(2):89-92. https://doi.org/10.1016/j.tim.2020.06.009. 
16. Worobey M, Gemmel M, Teuwen DE, Haselkorn T, Kunstman K, Bunce M, et al. Direct evidence of extensive diversity of HIV-1 in Kinshasa by 1960 Nature. 2008;455(7213):661-4. https://doi.org/10.1038/nature07390.

17. Morens DM, Taubenberger JK, Fauci AS. Predominant role of bacterial pneumonia as a cause of death in pandemic influenza: implications for pandemic influenza preparedness. J Infect Dis. 2008;198(7):962-70. https:// doi.org/10.1086/591708.

18. Why Archaeologists Love Digging Up Privies [https://archaeology.uiowa. edu/why-archaeologists-love-digging-privies].

19. Larmuseau MH, Bekaert B, Baumers M, Wenseleers T, Deforce D, Borry P, et al. Biohistorical materials and contemporary privacy concerns-the forensic case of king Albert I. Forensic Sci Int Genet. 2016;24:202-10. https://doi. org/10.1016/j.fsigen.2016.07.008.

20. Borry M, Cordova B, Perri A, Wibowo M, Prasad Honap T, Ko J, et al. CoprolD predicts the source of coprolites and paleofeces using microbiome composition and host DNA content. PeerJ. 2020;8:e9001. https://doi.org/10. 7717/peeri.9001.

21. Bouchet F, Harter S, Paicheler JC, Araujo A, Ferreira LF. First recovery of Schistosoma mansoni eggs from a latrine in Europe (15-16th centuries). J Parasitol. 2002;88(2):404-5. https://doi.org/10.1645/0022-3395(2002)088[0404: FROSME]2.0.CO:2.

22. SPIES IN THE SEWER: Visualizing an unexpected application of sewage analysis [https://www.wwdmag.com/spies-sewer-0].

23. The eDNA revolution [https://phe.rockefeller.edu/wp-content/uploads/2019/ 07/Sea-Technology-eDNA-editorial.pdf].

24. Stoeckle BC, Beggel S, Cerwenka AF, Motivans E, Kuehn R, Geist J. A systematic approach to evaluate the influence of environmental conditions on eDNA detection success in aquatic ecosystems. PLoS One. 2017;12(12): e0189119. https://doi.org/10.1371/journal.pone.0189119.

25. Thaler DS, Lipsitch M. Coronavirus: sampling now for future analysis. Nature. 2020;580(7805):590. https://doi.org/10.1038/d41586-020-01267-y.

26. Sharpe A, Barrios S, Gayer S, Allan-Perkins E, Stein D, Appiah-Madson HJ, et al. DESS deconstructed: is EDTA solely responsible for protection of high molecular weight DNA in this common tissue preservative? PLoS One. 2020; 15(8):e0237356. https://doi.org/10.1371/journal.pone.0237356.

27. Laurenza D, Kemp M. Leonardo da Vinci's codex Leicester: a new edition set: Oxford University press; 2020.

28. Adams A. Doctors as Architects. In: Architecture in the Family Way Doctors, Houses, and Women, 1870-1900: McGill-Queen's University Press; 1996. p. 36-72.

29. Levin H, Corsi R. Conceptual framework for building science in indoor microbiome studies. Indoor Air Hong Kong; 2014.

30. Thaler DS. Toward a microbial Neolithic revolution in buildings. Microbiome. 2016;4(1):14. https://doi.org/10.1186/s40168-016-0157-2

31. Thaler DS, Head MG, Horsley A. Precision public health to inhibit the contagion of disease and move toward a future in which microbes spread health. BMC Infect Dis. 2019;19(1):120. https://doi.org/10.1186/s12879-019-3 $715-y$.

32. La Rosa G, Mancini P, Bonanno Ferraro G, Veneri C, laconelli M, Bonadonna $L$, et al. SARS-CoV-2 has been circulating in northern Italy since December 2019: evidence from environmental monitoring. Sci Total Environ. 2021;750: 141711. https://doi.org/10.1016/j.scitotenv.2020.141711.

33. Kasper MR, Geibe JR, Sears CL, Riegodedios AJ, Luse T, Von Thun AM, et al. An outbreak of Covid-19 on an aircraft carrier. N Engl J Med. 2020;383(25): 2417-26. https://doi.org/10.1056/NEJMoa2019375.

34. Cohen J. Wuhan coronavirus hunter Shi Zhengli speaks out. Science. 2020; 369(6503):487-8. https://doi.org/10.1126/science.369.6503.487.

35. Singh D, Yi SV. On the origin and evolution of SARS-CoV-2. Exp Mol Med. 2021;53(4):537-47. https://doi.org/10.1038/s12276-021-00604-z.

36. Sallard E, Halloy J, Casane D, Decroly E, van Helden J. Tracing the origins of SARS-COV-2 in coronavirus phylogenies: a review. Environ Chem Lett. 2021: 1-17. Feb 4 online ahead of print.

37. Butler C, Canard B, Cap H, Chan Y, Claverie J, Colombo F, Courtier V, de Ribera F, Decroly E, de Maistre R, et al. Letter Seeking International Inquiry Into Origins of the Coronavirus. In: New York Times. 2021

38. Bloom JD, Chan YA, Baric RS, Bjorkman PJ, Cobey S, Deverman BE, et al. Investigate the origins of COVID-19. Science. 2021;372(6543):694. https://doi. org/10.1126/science.abj0016.

39. Meselson M, Guillemin J, Hugh-Jones M, Langmuir A, Popova I, Shelokov A, et al. The Sverdlovsk anthrax outbreak of 1979. Science. 1994;266(5188): 1202-8. https://doi.org/10.1126/science.7973702.
40. Ashton PS, Meselson M, Robinson JP, Seeley TD. Origin of yellow rain. Science. 1983;222(4622):366-8. https://doi.org/10.1126/science.222.4622.366.

41. Nowicke JW, Meselson M. Yellow rain--a palynological analysis. Nature. 1984 309(5965):205-6. https://doi.org/10.1038/309205a0.

42. Ahmed W, Angel N, Edson J, Bibby K, Bivins A, O'Brien JW, et al. First confirmed detection of SARS-CoV-2 in untreated wastewater in Australia: a proof of concept for the wastewater surveillance of COVID-19 in the community. Sci Total Environ. 2020;728:138764. https://doi.org/10.1016/j. scitotenv.2020.138764

43. Thaler R, Sunstein C. Nudge: improving decisions about health, wealth, and happiness Yale University press; 2008.

44. Gonzalez M, Mingorance MD, Sanchez L, Pena A. Pesticide adsorption on a calcareous soil modified with sewage sludge and quaternary alkylammonium cationic surfactants. Environ Sci Pollut Res Int. 2008;15(1):8-14. https://doi.org/10.1065/espr2007.02.387.

45. Sulej-Suchomska AM, Klupczynska A, Derezinski P, Matysiak J, Przybylowski $P$, Kokot ZJ. Urban wastewater analysis as an effective tool for monitoring illegal drugs, including new psychoactive substances, in the eastern European region. Sci Rep. 2020;10(1):4885. https://doi.org/10.1038/s41598-02 $0-61628-5$.

46. Perez-Lemus N, Lopez-Serna R, Perez-Elvira SI, Barrado E. Sample pretreatment and analytical methodology for the simultaneous determination of pharmaceuticals and personal care products in sewage sludge. Chemosphere. 2020;258:127273. https://doi.org/10.1016/j.chemosphere.202 0.127273

47. Golovko O, Orn S, Sorengard M, Frieberg K, Nassazzi W, Lai FY, et al. Occurrence and removal of chemicals of emerging concern in wastewater treatment plants and their impact on receiving water systems. Sci Total Environ. 2021;754:142122. https://doi.org/10.1016/j.scitotenv.2020.142122.

48. Nichols C, Bristow N, Ewing E, Gabriel J, Montoya B, Outka E. Reconsidering the 1918-19 Influenza Pandemic in the Age of COVID-19. J Gilded Age Progressive Era. 2020;19(4) published online: https://www.cambridge.org/ core/journals/journal-of-the-gilded-age-and-progressive-era/article/ reconsidering-the-191819-influenza-pandemic-in-the-age-of-covid191819/1 91815E191815A196456FF191817A191788BFD199927B534004895.

49. Friedman T. One Year Later, We Still Have No Plan to Prevent the Next Pandemic. In: New York Times. 2021.

50. Marquez G. The iconic first sentence "Many years later, as he faced the firing squad, Colonel Aureliano Buendía was to remember that distant afternoon when his father took him to discover ice." of One Hundred Years of Solitude; 1967.

\section{Publisher's Note}

Springer Nature remains neutral with regard to jurisdictional claims in published maps and institutional affiliations.

Ready to submit your research? Choose BMC and benefit from:

- fast, convenient online submission

- thorough peer review by experienced researchers in your field

- rapid publication on acceptance

- support for research data, including large and complex data types

- gold Open Access which fosters wider collaboration and increased citations

- maximum visibility for your research: over $100 \mathrm{M}$ website views per year

At BMC, research is always in progress.

Learn more biomedcentral.com/submissions 